\title{
Beden Eğitimi ve Spor Dersini Okutan Öğretmenlerin Okul İçi ve Dışı Spor Tesis, Araç ve Gereçlerden Yararlanma Durumlarının İncelenmesi (Niğde Örnĕ̆i)
}

\section{An Examination for the Usage of Sports Facility, Tools and Equipment in and out of School by Teachers who Conduct the Physical Education and Sports Course (Niğde Case)}

\author{
Yahya DOĞAR ${ }^{1}$
}

\begin{tabular}{|c|c|}
\hline $\begin{array}{l}\text { Anahtar Kelimeler } \\
\text { Spor araç ve gereçleri } \\
\text { İlkögretim } \\
\text { Beden eğitimi ve spor } \\
\text { dersi }\end{array}$ & 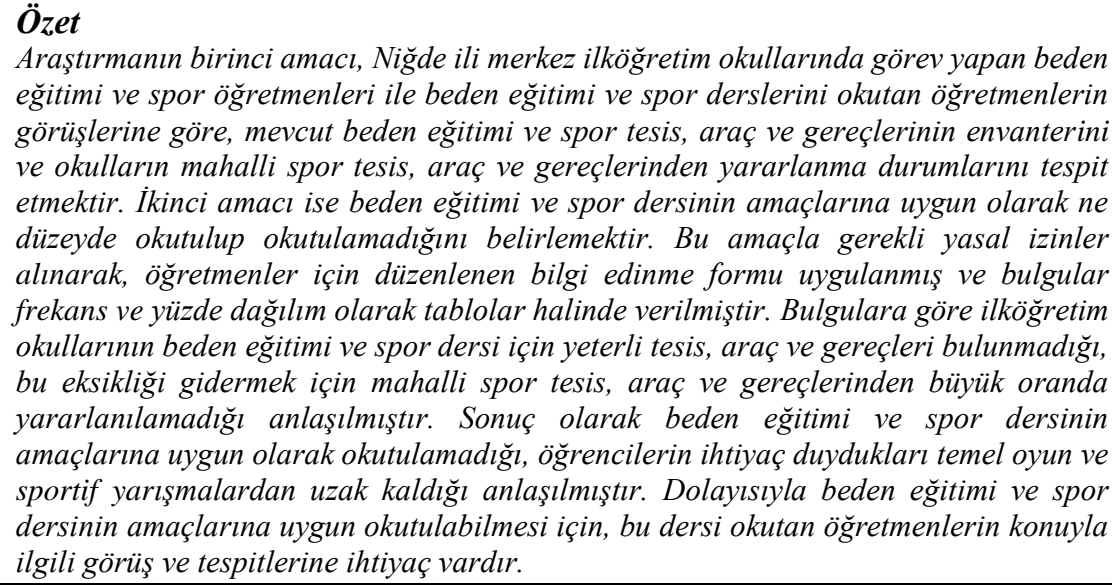 \\
\hline $\begin{array}{l}\text { Key Word } \\
\text { Sports equipment } \\
\text { Primary education, } \\
\begin{array}{l}\text { Physical education and } \\
\text { sport course }\end{array}\end{array}$ & $\begin{array}{l}\text { Abstract } \\
\text { The first aim of the study is to determine the inventory of the existing physical education } \\
\text { and sports facilities, tools and equipment and the condition of schools utilizing from the } \\
\text { local sports facilities, tools and equipment according to the views of physical education } \\
\text { and sports teachers and teachers who lecture on physical education and sports lesson } \\
\text { working in the primary schools of Nigde city center. The second aim of the course is to } \\
\text { determine that to what extent the physical education and sports course is applied in } \\
\text { accordance with the objectives of the course. For this purpose, the questionnaire forms } \\
\text { were issued to teachers after the necessary legal permissions were obtained and the } \\
\text { findings have been given as tables in frequency and percent distribution. According to } \\
\text { the findings, it is understood that primary schools do not have sufficient facilities, tools } \\
\text { and equipment for physical education and sports, and that local sports facilities, tools } \\
\text { and equipment cannot be utilized to fill this deficiency. As a result, it is inferred that } \\
\text { physical education and sports lesson cannot be conducted in accordance with its } \\
\text { objectives and the students are deprived of basic games and sports competitions they } \\
\text { needed. Therefore, in order to be able to teach the physical education and sports course } \\
\text { according to the aims of this lesson, there is a need for teachers' opinions and } \\
\text { determinations about this subject. }\end{array}$ \\
\hline
\end{tabular}

Atıf için: $\quad$ Doğar, Y. (2019). Beden eğitimi ve spor dersini okutan öğretmenlerin okul içi ve diş1 For Citation spor tesis, araç ve gereçlerden yararlanma durumlarının incelenmesi (Niğde örneği). Muğla Sıtkı Koçman Üniversitesi Eğitim Fakültesi [MSKU Journal of Education], 6(2), 109-119. DOI: $10.21666 /$ muefd.570831

\begin{tabular}{lll}
\hline Received: 27.05.2018 & Accepted: 04.10.2019 & Published: 01.11.2019 \\
\hline
\end{tabular}

\footnotetext{
${ }^{1}$ İönü Üniversitesi Spor Bilimleri Fakültesi, yahya.dogar@inonu.edu.tr Orcid: 0000-0002-1068-2266
} 
Beden eğitimi ve spor dersinin genel amaçlarına bakıldığında, temelinde küçük yaşlardan itibaren insanlara spor yapma alışkanlığ kazandırmak ve bunu bir yaşam kültürü haline getirmek yatmaktadır. Böyle bir durumun gerçekleşebilmesi için de, her şeyden önce beden eğitimi ve spor derslerinin amaçlarına uygun olarak okutulması gerekmektedir. Amaçların etkili ve verimli olarak gerçekleştirilmesi için de, öncelikle ders için gerekli olan insan ve madde kaynaklarının dersin ihtiyaçlarını karşılayacak nitelik ve nicelikte olması önemlidir. Türkiye eğitim ve öğretim şartlarında, anılan kaynakların hem nitel hem nicel açıdan yeterli olmadığı düşünüldüğünde, mevcut kıt ve yetersiz spor kaynakların ortaklaşa kullanılarak ve özellikle öğrencilerin hizmetine sunulması, kaynakların azami derecede etkili ve verimli kullanılmasından geçmektedir. Asıl önemli olan da, gerekli spor tesis, araç ve gereçlerin tedariki yanında, var olanların en etkin ve verimli şekilde kullanılabilmesidir.

Spor yapma ve spor kültürü oluşturmanın temeli, eğitimin ilk kademesinden itibaren atılmaktadır. Bu amaçla geleceğin güvencesi ve teminatı olan Türk gençliğinin genel eğitim süreci içerisinde daha sağl1klı, başarıl1, mücadele ve tahammül gücü yüksek insanlar yetiştirilmesinde, beden eğitimi ve spora ihtiyaç vardır. Bu ihtiyacı gidermenin en temel yolu da, ilköğretim okullarından itibaren bütün öğretim kurumlarında bilinçli olarak uygulanması gereken beden eğitimi ve spor dersidir (Sorguç, 1990). Beden eğitimi ve spor dersi çocukların hareket etme, motorsal beceriler yoluyla yaşantı, mücadele etme ve takdir edilme, başka çocuklarla oynama ihtiyaçlarını karılama yanında iyi duruş alışkanlığı, estetik, özgüven, kontrol ve disiplin duyguları geliştirme, sağlıklı ve mutlu yaşamaya istekli olma, doğaya sevgi, vatana sevgi, okul dışı sportif faaliyetlere karşı anlayışlı ve aktif olma gibi değerleri de geliştirir (Sönmez, 1985). Çünkü beden eğitimi ve spor genel eğitimin ayrılmaz bir parçasıdır (Bookwalter, 1969).

Beden Eğitimi ve Spor Derslerinin amaçlarına uygun olarak okutulabilmesi için uygun bir alan, yeterli tesis, araç ve gereç, beden eğitimi ve spor öğretmeni, ders için uygun giysi ve öğrenciye ihtiyaç vardır. Sıralanan bu ihtiyaçlardan herhangi birisinin eksikliği halinde, dersin amaç ve hedeflerine ulaşmasında eksik kalınacağı ve istenilen verimin alınamayacağı açıktır (Özener, 1988).

Mahalli, bölgesel yarışmalar ve Türkiye birinciliklerine katılan okullar incelendiğinde, bu okulların spor salonlarının olduğu, beden eğitimi ve spor için gerekli tesis, araç ve gerece sahip olduğu, mesleğini seven beden eğitimi öğretmenlerinin görev yaptığ 1 , okul yönetiminin ve diğer branş öğretmenlerinin beden eğitimini desteklediği hatta yardımcı oldukları gözlemlenmiştir (Öztürk ve Koçyiğit 1992).

$\mathrm{Bu}$ sebeple beden eğitimi ve spor derslerine gerekli önem verilerek, öğrencilerin spor tesis, araç ve gereç imkânlarından azami ve eşit düzeyde yararlanmaları gerekir. Okullarda anılan amaçların gerçekleştirilmesinde önemli ve etkin olan da beden eğitimi ve spor öğretmenleridir. Bu öğretmenler, kas etkinlikleri aracılığı ile çocuğun bedensel, ruhsal ve toplumsal bütünlüğünü zedelemeden, kendisinin ve böylece toplumun yararına optimal gelişimin eğitimini verirler (Koç, 1988). Beden eğitimi ve spor dersleri, fiziksel aktivitelere düzenli katılım ve genel olarak sağlıklı bir yaşam tarzının teşvik edilmesinde önemli rol oynar (Güllü ve ark. 2016).

$\mathrm{Bu}$ araştırmada beden eğitimi ve spor dersinin yukarda sıralanan amaçlarına uygun okutulması için gerekli olan spor tesis, araç ve gereçlerinin yeterliliği ve beden eğitimi derslerini okutan öğretmenlerin okul içi ve dışı spor tesis, araç ve gereçlerinden yaralanma durumları incelenmiştir. Ayrıca okul yönetimi, veli ve öğrenci davranışlarına göre konu aydınlatılarak pekiştirilmeye çalışılmıştır. Böyle bir konunun araştırılmasının, beden eğitimi ve spor dersinin daha etkili ve verimli okutulmasında gerekli olabilecek yol, yöntem ve usullerin belirlenmesine katkı sağlayacağı düşünülmektedir.

\section{Araştırmanın Modeli}

\section{Yöntem}

$\mathrm{Bu}$ araştırma nicel yöntemli betimsel tarama modelinde bir araştırmadır. Tarama modeli, geçmişte ya da halen var olan bir durumu var olduğu şekliyle betimlemeyi amaçlayan araştırma yaklaşımıdır. Araştırmaya konu olan olay, birey ya da nesne, kendi koşuları içinde ve olduğu gibi tanımlamaya 
çalış1lır. Önemli olan bilinmek istenileni ygun bir biçimde gözlemleyip belirleyebilmektir (Karasar 1998).

\section{Evren ve Örneklem}

Araştırmanın evrenini Niğde il merkezine bağlı 75 ilköğretim okulunda görev yapan 75 beden eğitimi ve spor öğretmeni oluşturmaktadır. Örneklem evrenin tamamını kapsamaktadır. Araştırma için öncelikle gerekli yasal izinler alınmış, veriler uzman görüşü alınarak hazırlanan anket formu aracılığı ile toplanmıştır. Anket formunda spor tesis, araç ve gereçlerin mevcut durumu, okul dış1 spor tesis, araç ve gereçlerden yararlanma durumu, mahalli idarelerin beden eğitimi ve spor faaliyetlerine ne ölçüde destek olduğu, okul yöneticilerinin spora karşı ilgileri gibi sorular yer almıştır. Okul içi spor tesis ve araçlarının yeterliliği ise beden eğitimi öğretmenleri ile yüz yüze görüşme tekniğiyle tespit edilmiştir.

\section{Verilerin Analizi}

Verilerin analizi IBM Statistics (SPSS versiyon, 22.0, NY, USA) paket programıla yapıldı. Veriler frekans (f) ve yüzde (\%) olarak değerlendirildi.

\section{Bulgular}

$\mathrm{Bu}$ bölümde, çalışma grubuna ilişkin veriler tablolar haline dönüştürülerek incelenmiş, yüzde ve frekans dağılımlarıyla açıklanmıştır.

Tablo 1: Sayısal Dağılım

\begin{tabular}{ll}
\hline Beden Eğitimi ve Spor Öğretmeni & 75 \\
\hline Okullardaki Toplam Oyun Alanı $\left(\mathrm{m}^{2}\right)$ & $166,350 \mathrm{~m}^{2}$ \\
\hline Okullardaki Toplam Öğretmen Sayısı & 1013 \\
\hline Okullardaki Toplam Öğrenci Sayısı & 26,311 \\
\hline Okul Başına Düş̧en Oyun Alanı $\left(\mathrm{m}^{2}\right)$ & $2,218 \mathrm{~m}^{2}$ \\
\hline Öğrenci Başına Düşen Oyun Alanı $\left(\mathrm{m}^{2}\right)$ & $6,32 \mathrm{~m}^{2}$ \\
\hline
\end{tabular}

Tablo 1'e göre, okullardaki Toplam Oyun Alanı 166,350 m2 iken, Okul Başına Düșen Oyun Alanı 2,218 m2, öğrenci başına düşen oyun alanı ise $6.32 \mathrm{~m}^{2}$ olduğu görülmektedir. Okullardaki Toplam Öğretmen Sayısının 1013, Okullardaki Toplam Öğrenci Sayısının 26,31 olduğu tespit edilmiştir.

Tablo 2: Okulların Kapalı Spor Alanları

\begin{tabular}{ccc} 
Durum & Okul Sayıs 1 & $\%$ \\
\hline Yok & 73 & 97.3 \\
\hline Var & 2 & 2.7 \\
\hline Toplam & 75 & 100.0 \\
\hline
\end{tabular}

Tablo 3: Okul Dışı Spor Tesis, Araç ve Gereçlerden Yararlanma Durumu

\begin{tabular}{lcc}
\hline Değer & $\mathrm{f}$ & $\%$ \\
\hline Hiç & 13 & 17,3 \\
\hline Kısmen & 51 & 68,0 \\
\hline Bazan & 8 & 10,7 \\
\hline Sik Sik & 3 & 4,0 \\
\hline Toplam & 75 & 100,0 \\
\hline
\end{tabular}


Tablo 3'e göre beden eğitimi ve spor öğretmenlerinin okul dışı spor tesis, araç ve gereçlerden büyük oranda kısmen yararlandıkları anlaşıılmaktadır.

Tablo 4: Okul Dışı Spor Tesis, Araç ve Gereçlerden Yararlanamama Nedenleri

\begin{tabular}{|c|c|c|c|c|c|c|c|c|}
\hline \multicolumn{3}{|c|}{ Okul Dışı Saha Ve Malzeme } & \multicolumn{3}{|c|}{ Zaman } & \multicolumn{3}{|c|}{ Okul İdaresinin İzni } \\
\hline Değer & $\mathrm{f}$ & $\%$ & Değer & $\mathrm{f}$ & $\%$ & Değer & $\mathrm{f}$ & $\%$ \\
\hline Var & 62 & 82,7 & Var & - & - & Var & - & - \\
\hline Yok & 13 & 17,3 & Yok & 75 & 100,0 & Yok & 75 & 100,0 \\
\hline Toplam & 75 & 100,0 & Toplam & 75 & 100,0 & Toplam & 75 & 100,0 \\
\hline \multicolumn{3}{|c|}{ Saha Ve Malzeme Kullanımına İzin } & \multicolumn{3}{|c|}{ Saha Ve Malzeme Ücretli } & \multicolumn{3}{|c|}{ Saha Eve Uzak } \\
\hline Değer & $\mathrm{f}$ & $\%$ & Değer & $\mathrm{f}$ & $\%$ & Değer & $\mathrm{f}$ & $\%$ \\
\hline Var & 1 & 1,3 & Ücretsiz & - & - & Evet & 73 & 97,3 \\
\hline Yok & 74 & 98,7 & Ücretli & 75 & 100,0 & Hayır & 2 & 2,7 \\
\hline Toplam & 75 & 100,0 & Toplam & 75 & 100,0 & Toplam & 75 & 100,0 \\
\hline
\end{tabular}

Tablo 4'e göre okul dışı spor tesis, araç ve gereçlerden yararlanamama nedenleri olarak, kullanım izinlerinin olmaması, yetersizlik ve ücretli oluşu gösterilmektedir.

Tablo 5: Mahalli İdarelerden Beden Eğitimi Ve Spor Faaliyetleri İçin İstek

\begin{tabular}{ccc}
\hline Değer & $\mathrm{f}$ & $\%$ \\
\hline Talepte bulunmadım & 22 & 29,3 \\
\hline Talapte bulundum & 53 & 70,7 \\
\hline Toplam & 75 & 100,0 \\
\hline
\end{tabular}

Tablo 6: İstek Sonrası Mahalli İdarelerden Alınan Yardım

\begin{tabular}{cccccc}
\hline \multicolumn{2}{c}{ Yardım Edilmedi } & \multicolumn{3}{c}{ Maddi Yardım } \\
\hline Değer & $\mathrm{f}$ & $\%$ & Değer & $\mathrm{f}$ & $\%$ \\
\hline Yardım yapılmadı & 37 & 49,3 & Yardım yapılmadı & 71 & 94,7 \\
\hline Yardım yapıldı & 38 & 50,7 & Yardım yapıldı & 4 & 5,3 \\
\hline Toplam & 75 & 100,0 & Toplam & 75 & 100,0 \\
\hline Ayni Yardım & & & & Saha Tahsisi & \\
\hline Değer & $\mathrm{f}$ & $\%$ & Değer & $\mathrm{f}$ & $\%$ \\
\hline Yardım yapılmadı & 64 & 85,3 & Yardım yapılmadı & 52 & 69,3 \\
\hline Yardım yapıldı & 11 & 14,7 & Yardım yapıldı & 23 & 30,7 \\
\hline Toplam & 75 & 100,0 & Toplam & 75 & 100,0 \\
\hline
\end{tabular}

Tablo 7: Beden Eğitimi Ve Spor Dersinin Daha İyi Okutulması İçin Okul Yönetiminin Yardımı

\begin{tabular}{ccc}
\hline Değer & $\mathrm{f}$ & $\%$ \\
\hline Hayır & 4 & 5,3 \\
\hline Kismen & 50 & 66,7 \\
\hline Sik sik & 21 & 28,0 \\
\hline Toplam & 75 & 100,0 \\
\hline
\end{tabular}


Tablo 8: Okul Yöneticilerinin Özel Olarak Sporla İlgilenmeleri

\begin{tabular}{ccc}
\hline Değer & $\mathrm{f}$ & $\%$ \\
\hline İlgilenmiyor & 40 & 53,7 \\
\hline İlgileniyor & 35 & 46,7 \\
\hline Toplam & 75 & 100,0 \\
\hline
\end{tabular}

Tablo 9: Okul Yöneticileri Tarafından Tercih Edilen Spor Branşı

\begin{tabular}{ccc}
\hline Değer & $\mathrm{f}$ & $\%$ \\
\hline Yok & 41 & 54,7 \\
\hline Var & 34 & 45,3 \\
\hline Toplam & 75 & 100,0 \\
\hline
\end{tabular}

Tablo 10: Okul Yönetiminin Okul Aile İşbirliği Toplantılarında Beden Eğitimi Ve Sporla İlgili Konuları Gündeme Getirme

\begin{tabular}{ccc}
\hline Değer & $\mathrm{f}$ & $\%$ \\
\hline Hayır & 6 & 8,0 \\
\hline Evet & 69 & 92,0 \\
\hline Toplam & 75 & 100,0 \\
\hline
\end{tabular}

Tablo 11: Okul Aile Birliğinin Beden Eğitimi Ve Spor Dersine Desteği

\begin{tabular}{ccc}
\hline Değer & f & $\%$ \\
\hline Yok & 9 & 12,0 \\
\hline Kismen & 59 & 78,7 \\
\hline Yeteri kadar & 7 & 9,3 \\
\hline Toplam & 75 & 100,0 \\
\hline
\end{tabular}

Tablo 12: Beden Eğitimi Ve Spor İçin Ayrılan Ders Saati Müfredat İçin Yeterliliği

\begin{tabular}{ccc}
\hline Değer & $\mathrm{f}$ & $\%$ \\
\hline Hayır & 20 & 26,7 \\
\hline Evet & 55 & 73,3 \\
\hline Toplam & 75 & 100,0 \\
\hline
\end{tabular}

Tablo 13: Beden Eğitimi Ve Spor Dersi Saati Haftada Kaç Saat Olmalı

\begin{tabular}{ccc}
\hline Değer & $\mathrm{f}$ & $\%$ \\
\hline 2 saat & 28 & 37,3 \\
\hline 4 saat & 36 & 48,0 \\
\hline 6 saat & 11 & 14,7 \\
\hline Toplam & 75 & 100,0 \\
\hline
\end{tabular}

Tablo 14: Öğrencilerin Derslere Uygun Beden Eğitimi Ve Spor Kıyafetiyle Katılımı

\begin{tabular}{lcc}
\hline \multicolumn{1}{c}{ Değer } & $\mathrm{f}$ & $\%$ \\
\hline Uygun değil & 1 & 1,3 \\
\hline Kismen uygun & 64 & 85,3 \\
\hline Tamamen uygun & 10 & 13,3 \\
\hline Toplam & 75 & 100,0 \\
\hline
\end{tabular}


Tablo 15: Öğrencilerin Derslere Uygun Beden Eğitimi Ve Spor Kıyafetiyle Katılmama Nedenleri

\begin{tabular}{ccc}
\hline \multicolumn{1}{c}{ Değer } & $\mathrm{f}$ & $\%$ \\
\hline İlgisizlik & 5 & 6,7 \\
\hline Ekonomik yetersizlik & 66 & 88,0 \\
\hline Ailenin tutumu & 4 & 5,3 \\
\hline Toplam & 75 & 100,0 \\
\hline
\end{tabular}

Tablo 16: Öğrencilerin Ders Dışı Sportif Faaliyetlere Katılma Düzeyleri

\begin{tabular}{lcc}
\hline \multicolumn{1}{c}{ Değer } & $\mathrm{f}$ & $\%$ \\
\hline Zayıf & 10 & 13,3 \\
\hline Orta düzeyde & 58 & 77,3 \\
\hline Yüksek düzeyde & 7 & 9,3 \\
\hline \multicolumn{1}{c}{ Toplam } & 75 & 100,0 \\
\hline
\end{tabular}

Tablo 17: Öğrencilerin Ders Dışı Spor Takımlarının Oluşturulması

\begin{tabular}{ccc}
\hline Değer & $\mathrm{f}$ & $\%$ \\
\hline Hayır & 6 & 8,0 \\
\hline Evet & 69 & 92,0 \\
\hline Toplam & 75 & 100,0 \\
\hline
\end{tabular}

Tablo 18: Okul Spor Takımlarının Oluşturulamama Sebepleri

\begin{tabular}{cccccc}
\hline & Öğrenci İsteksizliği & \multicolumn{3}{c}{ Saha Ve Malzeme Yetersizliği } \\
\hline Değer & $\mathrm{f}$ & $\%$ & Değer & $\mathrm{f}$ & $\%$ \\
\hline Hayır & 72 & 96,0 & Hayır & 72 & 96,0 \\
\hline Evet & 3 & 4,0 & Evet & 3 & 4,0 \\
\hline Toplam & 75 & 100,0 & Toplam & 75 & 100,0 \\
\hline & Öğretmenin Vakti Yok & & & Öğrencilerin İlgisizliği & \\
\hline Değer & $\mathrm{f}$ & $\%$ & Değer & $\mathrm{f}$ & 100,0 \\
\hline Hayır & 75 & 100,0 & Hayır & 75 & - \\
\hline Evet & - & - & Evet & - & 100,0 \\
\hline Toplam & 75 & 100,0 & Toplam & 75 & \\
\hline
\end{tabular}

Tablo 18'e göre öğrencilerin istekli olmasına rağmen okul takımlarının oluşturulamamasında öğretmenin zamanının yetersizliğinin ve öğrencilerin ilgisizliğinin ön plana çıktığg görülmektedir.

Tablo 19: Öğrenciye Beden Eğitimi Ve Spor Dersini Okutma Yöntemleri

\begin{tabular}{ccc}
\hline Değer & $\mathrm{f}$ & $\%$ \\
\hline Önce teorik, sonra uygulama & 17 & 22,7 \\
\hline Önce uygulama, sonra teorik & 36 & 48,0 \\
\hline Uygulama esnasinda teorik & 22 & 29,3 \\
\hline Toplam & 75 & 100,0 \\
\hline
\end{tabular}


Tablo 20: İl Milli Eğitim Müdürlüğünce Planlanan Sportif Faaliyetlerden Okulları Bilgilendirmesi

\begin{tabular}{ccc}
\hline Değer & $\mathrm{f}$ & $\%$ \\
\hline Bilgilendirmiyor & 8 & 10,7 \\
\hline Bilgilendiriyor & 67 & 89,3 \\
\hline Toplam & 75 & 100,0 \\
\hline
\end{tabular}

Tablo 21: Mahalli İdarelerin Eğitim Kurumlarına Yardım Yapma

Zorunluluğunun Bilinmesi

\begin{tabular}{ccc}
\hline Değer & $\mathrm{f}$ & $\%$ \\
\hline Hayır & 31 & 41,3 \\
\hline Evet & 44 & 58,7 \\
\hline Toplam & 75 & 100,0 \\
\hline
\end{tabular}

Tablo 22: Öğrencilerin Boş Zamanlarında Sosyal Faaliyetlerle İlgilenme Durumları

\begin{tabular}{|c|c|c|c|c|c|c|c|c|}
\hline \multicolumn{3}{|c|}{ Ders Çalışma } & \multicolumn{3}{|c|}{ Sporla Uğraşma } & \multicolumn{3}{|c|}{ Sinemaya Gitme } \\
\hline Değer & $\mathrm{f}$ & $\%$ & Değer & $\mathrm{f}$ & $\%$ & Değer & $\mathrm{f}$ & $\%$ \\
\hline 1 & 65 & 86,7 & 1 & 6 & 8,0 & 1 & - & - \\
\hline 2 & 5 & 6,7 & 2 & 37 & 49,3 & 2 & - & - \\
\hline 3 & 3 & 4,0 & 3 & 20 & 26,7 & 3 & 3 & 4,0 \\
\hline 4 & 1 & 1,3 & 4 & 8 & 10,7 & 4 & 3 & 4,0 \\
\hline 5 & - & - & 5 & 4 & 5,3 & 5 & 19 & 25,3 \\
\hline 6 & 1 & 1,3 & 6 & - & - & 6 & 50 & 66,7 \\
\hline Toplam & 75 & 100,0 & Toplam & 75 & 100,0 & Toplm & 75 & 100,0 \\
\hline \multicolumn{3}{|c|}{ Kütüphaneye Gitme } & \multicolumn{3}{|c|}{ Ailesi İle Birlikte Olma } & \multicolumn{3}{|c|}{ Oyun Oynama } \\
\hline Değer & $\mathrm{f}$ & $\%$ & Değer & $\mathrm{f}$ & $\%$ & Değer & $\mathrm{f}$ & $\%$ \\
\hline 1 & 1 & 1,3 & 1 & 1 & 1,3 & 1 & 2 & 2,7 \\
\hline 2 & 7 & 9,3 & 2 & 15 & 20,0 & 2 & 11 & 14,7 \\
\hline 3 & 10 & 13,3 & 3 & 26 & 34,7 & 3 & 13 & 17,3 \\
\hline 4 & 14 & 18,7 & 4 & 15 & 20,0 & 4 & 33 & 44,0 \\
\hline 5 & 29 & 38,7 & 5 & 12 & 16,0 & 5 & 11 & 14,7 \\
\hline 6 & 14 & 18,7 & 6 & 6 & 8,0 & 6 & 5 & 6,7 \\
\hline Toplam & 75 & 100,0 & Toplam & 75 & 100,0 & Toplm & 75 & 100,0 \\
\hline
\end{tabular}

Tablo 22'ye göre beden eğitimi ve spor öğretmenleri, öğrencilerin boş zamanlarını birinci sırada ders çalışmalı (\%86.7), sporla uğraşmalı (\%8), sinemaya gitmeli (\%4), kütüphaneye gitmeli (\%1.3), ailesi ile birlikte olmalı ( \%1.3) ve oyun oynamalıdır( \%2.7) şeklinde ifade etmişlerdir

Not: Her seçenek öncelik sırasına göre numaralandırılmıştır.

Tablo 23: Derse Spor Kıyafeti İle Gelmeyen Öğrencilerin Derse Alınma Durumu

\begin{tabular}{lcc}
\hline \multicolumn{1}{c}{ Değer } & f & $\%$ \\
\hline Kesinlikle alınmamalı & 9 & 12,0 \\
\hline Kesinlikle alınmalı & 6 & 8,0 \\
\hline Derse alınmalı ve kenarda bekletilmeli & 57 & 76,0 \\
\hline Başka işle görevlendirilmeli & 3 & 4,0 \\
\hline \multicolumn{1}{c}{ Toplam } & 75 & 100,0 \\
\hline
\end{tabular}




\section{Tartışma}

Niğde il merkezinde bulunan 75 ilköğretim okulunda, öğrenci başına düşen oyun ve gezinti alanı 6,32 $\mathrm{m}^{2}$ dir (Tablo 1). İlköğretim okullarında gezi ve oyun alanları ölçüsü, Türkiye standartlarının üzerindedir. Örneğin Ankara kent ölçeğinde $2.2 \mathrm{~m}^{2}$, İstanbul'da $1 \mathrm{~m}^{2}$, İzmir'de $2.3 \mathrm{~m}^{2}$, Eskişehir'de $1.2 \mathrm{~m}^{2}$ 'dir. Buna karşın Amerika Birleşik Devletlerinde kent düzeyinde açık-yeşil alan normu, $40 \mathrm{~m} 2$ kabul edilmektedir. Ancak 3194 sayılı İmar Kanununun, 1999 yılında çıkarılan 23804 sayılı yönetmeliğe göre, belediye olan yerlerde nüfus ne olursa olsun kişi başına aktif yeşil alan miktarı (park, çocuk bahçesi ve oyun alanlarının toplamı) $10 \mathrm{~m}^{2}$ olarak belirlenmiştir (Gül ve ark. 2001). Bu değerlerin yabancı ülke kentlerine oranla çok düşük olması, yaşam kalitesi anlamında olumsuzlukları da beraberinde getirdiği şekilde açıklanabilir (Semih ve ark. 2007)

Birinci ve beşinci sınıflarda öğretmen başına düşen öğrenci sayısı 27,3; altı ve sekizinci sınıflarda ise 24 olarak tespit edilmiştir. 2009-2012 yılları arasında Türkiye İstatistik Kurumu verilerine göre Türkiye genelinde öğretmen başına düşen öğrenci oranı ortalama 21'dir (TÜİK). Buna göre öğretmen başına düşen öğrenci sayısı Niğde merkez ilköğretim okullarında Türkiye ortalamasının üzerinde çıkmıştır. Niğde ili merkeze bağlı ilköğretim okullarındaki beden eğitimi öğretmeni sayısı ise 61dir (Tablo 1).

75 ilköğretim okulunun sadece ikisinde kapalı spor salonu bulunmaktadır (Tablo 2). Ayrıca açık spor alanları olarak 75 ilköğretim okulunun oyun alanlarının yetersiz oluşu, beden eğitimi ve spor derslerinin amaçlarına ulaşmasında önemli bir eksiklik kabul edilebilir. Bu durumda ilköğretim okullarının kapalı spor alanı olarak yetersiz olduğu, yine beden eğitimi ve spor derslerinin yürütülmesinde gerekli olan tesis, araç, gereç ve donanımın da hem nitelik hem de nicelik açısından uygunsuz olduğu ve müfredata bağlı konuların işlenmesinde amaca ulaşılmayacağı ortaya çıkmaktadır. Dolayısıyla okul içi, bölgesel ve Türkiye genelinde yapılan sportif faaliyet ve yarışmalara da katılım da az olacaktır. Oysa nitelikli oyun firsatını elde eden çocuğun yaratıcı olduğu, problem çözme konusuna esnek yaklaştığı, daha iyi sosyal ilişkilere sahip olduğu ve fiziksel olarak daha sağlıklı olduğu bilinen bir gerçektir (Yılmaz ve ark. 2002). Bu konuda nasıl ki kapısız penceresiz bir ev düşünülemiyorsa, spor salonsuz da bir okul düşünülmemelidir. Özellikle Niğde ili gibi iklimin soğuk geçtiği bir coğrafyada, kapalı oyun alanı ihtiyacı daha da artmaktadır.

Okul dış1 spor tesis, araç ve gereçlerden yararlanma durumuna göre öğretmenlerin \%13'ü hiç yararlanmadıklarını ifade ederken, \%51 kısmen, \% 8'ibazan ve \%3'ü de sık sık yararlandıklarını ifade etmişlerdir (Tablo 3). Öğretmenler okul dış1 spor tesis, araç ve gereçlerinden yararlanamama nedenleri konusunda da \%17,3'ü saha, araç ve gereç yokluğu, \%100'ü zamanın yetersizliğini, okul idaresinin izin vermediğini, saha ve malzeme kullanımının ücretli olduğunu ve spor tesis, araç ve gereçlerin okul ortamına uzak olduğunu, \%98,7'si de spor tesis, araç ve gereçlerin kullanımına izin verilmediğini ifade etmişlerdir (Tablo 4). Spor saha ve malzemelerden yeteri kadar yararlandığını belirten öğretmenlerin görev yaptıkları okulların, spor tesislerine yakın olması, beden eğitimi ve spor derslerinin okutulmasında öğrenciler adına olumlu kabul edilebilir. Bu durum mahallin okul dışı spor tesis, araç ve gereçlerinin okullara yakın yapılmasını önemli hale getirmektedir. Dolayısıyla bir spor tesisi ya da okul yapımı planlanırken, eğitim kurumları ile spor tesislerinin birlikte ele alınmasını gerekli kılmaktadır.

Beden eğitimi ve spor öğretmenlerinin \%70,7'si spor tesis, araç ve gereç talebinde bulunmasına rağmen (Tablo 5), mahalli idarelerce \%5,3'üne maddi,\%14,7'sine ayni, \%30,7'sine de saha tahsisi yardımları yapıldığı, \%50,7'si de hiç yardım yapılmadığını ifade etmişlerdir (Tablo 6). Bu verilere göre mahalli idareler, talebin çok olmasına rağmen, talebe düşük oranda cevap verebilmişlerdir. Durum okul dışı saha, tesis ve araç, gereçlerden ilköğretim okullarının yeterince yararlanamadıklarını göstermektedir. Ayrıca konu mahalli idarelerin yardım konusunda yeterli spor tesis, araç ve gerece sahip olmadıkları şeklinde de değerlendirilebilir. Ancak az da olsa bir kısım okulların mahalli imkânlardan yaralanmaları, eğitim ve öğretimde firsat eşitsizliğini de gündeme getirmektedir.

Beden eğitimi ve spor dersinin daha etkili ve verimli okutulması için okul yöneticilerinin \%66.7'nin kısmen, \%28'inin yeteri kadar ve \%5.3'ünün de hiç yardım yapmamaları düşündürücüdür (Tablo 7). 
Hâlbuki okulu müdür yönetir ve müdür tüm derslerin en etkili ve verimli okutulması için gerekli ihtiyaçları karşılamaktan ve ilgili öğretmenin hizmetine sunmaktan birinci derecede sorumludur. Osborne'a (1984) göre eğitim, bireyin yaratıcılığını, özerkliğini ve eleştirici ruhunu geliştirmeli ve onda var olan potansiyeli ortaya çıkarmasını sağlayarak, öğrencilerin gizil güçlerini açığa çıkarmalıdır.

Okul idarecilerinin \%53.7'sinin sporla ilgilenmemesi (Tablo 8), \%54.7'sinin okul spor faaliyetlerinde özel olarak bir spor branş tercihlerinin olmaması (Tablo 9), anılan dersin etkili ve verimli okutulabilmesinde yöneticilerin $\% 66,7$ oranında kısmen desteklediklerini bir anlamda doğrulamaktadır. Bu durumda okul idarecilerinin çoğunluğunun sporla uğraşmadığı ve spora özel bir eğilimi olmadığı da ortaya çıkmaktadır. Bu durum okul müdürlerinin spora ilgi duyan ve onun yararlarını yaşayarak öğrencilere örnek teşkil etmesi bakımından önemlidir. Gaikwad (2004), eğitimcinin davranışlarını öğrencilerden beklenen davranışların gerçekleşmesini veya kazanılmasını sağlayacak şekilde düzenlemelerini önermektedir. Dolayısıyla konu ile ilgili olarak okul yöneticilerinin seçiminde spora karşı ilgilerinin de dikkate alınması yararlı olacaktır.

Okul yönetiminin okul aile birliği toplantılarında, beden eğitimi ve sporla ilgili konuları gündeme getirmesi konusunda, beden eğitimi ve spor öğretmenlerinin \%92'si, gündeme getirildiği şeklinde görüş bildirmişler (Tablo 10), ancak okul aile birliği üyelerinin \% 78.7'sinin kısmen ilgilendiği ortaya çıkmıştır (Tablo 11). Tablo 7 ve 8 değerlerine göre böyle bir sonucun çıkması, yöneticilerin konuyu gündeme getirmelerinin yasal zorunluluktan kaynaklandığı şeklinde değerlendirmek mümkündür. Ya da konuyu, sporu seven velilerin yönetime hatırlatmasından kaynaklandığı biçiminde de değerlendirmek daha doğru olabilir. Diğer taraftan çoğunlukla velilerin konuya kısmen ilgi göstermeleri, toplumun spor kültürünün zayıflığı yanında, okul yöneticilerinin yeterince velileri beden eğitimi ve spor konusunda aydınlatamamış olmalarından da kaynaklanabilir.

Tablo 12'de, beden eğitimi öğretmenlerinin \%73.3'ü beden eğitimi dersine ayrılan ders saatinin, müfredatı takip etmekte yeterli, \%26.7'si ise yetersiz olduğu görüşündedirler. Ders saatlerinin çoğunlukla yeterli görülmesi, ders için gerekli olan tesis, araç ve gereçlerin yetersiz olmasından kaynaklanabilir.

Tablo 13'e göre beden eğitimi öğretmenlerinin \%48'i 4 saatin yeterli olacağ1 şeklinde görüş belirtirken, \%37.3'lük kısmı 2 saatin ders için yeterli olacağını, \%14.7'lik bölümü ise ders için 6 saatin gerekli olduğunu belirtmiştir.

Tablo 14'e göre öğretmenler, öğrencilerin beden eğitimi dersine uygun ders kıyafeti ile katılımı konusunda öğretmenlerin \%85.3'ü kısmen uygun, \%13.3'ü uygun kıyafetle katıldıklarını ifade ederken, \%1.3'ü de uygun olmayan kıyafetle derse katıldıklarını ifade etmişlerdir. Öğretmenler öğrencilerin beden eğitimi ve spor dersine ders kıyafeti ile katılmama sebeplerini \%88 oranında ekonomik yetersizlik, \%6.7 oranında derse karşı ilgisizlik ve \%5.3 oranında da ailelerin tutumları şeklinde değerlendirmişlerdir (Tablo 15). Öğrencilerin sportif faaliyetlere katılma düzeylerinin \%77.3 oranında orta düzeyde olması (Tablo 16) konunun Tablo 14 ve 15 değerleri ile iç içe olduğunu göstermektedir.

Öğretmenlerin \%92 oranında ders dışı sportif faaliyet olarak takım oluşturduğu (Tablo 17), ancak ders dışı spor faaliyetleri için takım oluşturamamanın sebepleri olarak da, \%4 oranında öğrenci isteksizliği, $\% 4$ oranında ise saha ve malzeme yetersizliği gösterilmiştir (Tablo 18). Bu durumu, sportif faaliyetler için ders dışı takım oluşturmada, spor tesis, araç ve gereçlerinin çok da etkin olmadığı, bunun dışında ögretmen, okul yönetimi ve veliler gibi etkenlerin daha önemli olduğu şeklinde değerlendirmek mümkündür. Demirel'in (2004) de belirttiği gibi, özellikle bireylerin gereksinimlerini ve yaratıcı çalışmalarını ortaya çıkarıcı ders dışı etkinliklere yer verildiği takdirde ders programlarının amaçlarına ulaşmaları daha iyi sağlanabilecektir.

Öğretmenler derslerin okutulmasında, \%48 oranında önce uygulama sonra teorik, \%29.3 oranında uygulama ve teorik, \%22.7 oranında ise önce teorik sonra uygulama yöntemini kullandıklarını belirtmişlerdir (Tablo 19). Çumralıgil'e göre (1995), etkili ve verimli bir beden eğitimi ve spor dersi için, sözlü anlatımın çok kısa tutulması, gösteri yönteminin ise daha aktif olarak kullanılmasının daha doğru olduğu vurgulanmıştır. Gösteri yönteminde kazandırılması istenen hareketlerin ve becerilerin 
görsel ve işitsel olarak açıklanması vardır. Gösteri esnasında davranışların yavaş yapılması, ince ayrıntıların açıklanması, soruların cevaplanması ve sonunda tartışılması gerekir. Bu yöntem, gözlem yolu ile öğrenmeyi sağlar ve öğrencinin güdülerinin pratiğe aktarılmasını kolaylaştırır (Erden ve Fidan1986). Dolayısıyla Karma yöntem içerisinde anlatıma daha az yer verilerek büyük bölümün gösteri yöntemine ayrılması, öğrenciler açısından daha yararlı olacaktır.

Tablo 20'ye göre; il milli eğitim müdürlüğünün planlamış olduğu sportif faaliyetlerde \%89.3 oranında öğretmenleri bilgilendirdiği, Tablo 21'e göre de, mahalli idarelerin spora katkı yapma zorunluğu olduğunu \%58.7 oranında öğretmenlerin bildiği, \%41.3'ünün de bilmediği anlaşılmaktadır. Beden eğitimi ve spor öğretmenlerinin az sayıda da olsa planlanan sportif faaliyetlerden haberdar olmaması, ayrıca yarıya yakın öğretmenin mahalli idarelerin sportif faaliyetlerle ilgili okullara yönelik yardım yapma zorunluluğunu bilmemesi, beden eğitimi ve spor dersinin amaçlarına uygun olarak okutulabilmesinde önemli bir eksiklik ve ilgisizlik olarak değerlendirilebilir. Halbuki kanunlar herkesi bağlar. Türkiye'nin geleceğini oluşturan çocukların karşısında sorumluluklarımız bulunmaktadır. Bu sorumlulukların en önemlilerinden biri de çocuklarımızın oyun ve spor hakkıdır (Kasap ve ark. 2005).

Tablo 22'ye göre beden eğitimi ve spor öğretmenleri, öğrencilerin boş zamanlarını birinci sırada ders çalışmalı (\%86.7), sporla uğraşmalı (\%8), sinemaya gitmeli (\%4), kütüphaneye gitmeli (\%1.3), ailesi ile birlikte olmalı ( \%1.3) ve oyun oynamalıdır( \%2.7) şeklinde ifade etmişlerdir. Oyun ihtiyacı karşılanamayan bir çocuğun, derse karşı kendini ne derecede adapte edeceği, nasıl rahatlayacağı, arkadaşlarıyla nasıl iletişim kuracağı, nasıl sosyalleşeceği, daha sağlıklı nasıl olacağı gibi konular düşündürücüdür. Özellikle beden eğitimi ve spor öğretmenlerinin $\% 86,7$ gibi bir oranda ve birinci planda öğrencilerin ders çalışmalarını, \%8'inin sporla ve \%2,7'sinin de oyunla ilgilenmelerini gerekli görmeleri, yapmaları gereken işleriyle yaptıkları arasındaki çelişkileri ortaya çıkarması bakımından anlamlıdır. Oysa beden eğitimi ve spor, genel eğitimin ayrılmaz bir parçasıdır.

Beden eğitimi spor dersine spor kıyafeti ile gelmeyen öğrenci konusunda öğretmenlerin \% 76 'sı derse alınmalı fakat kenarda bekletilmeli, \%12'si derse kesinlikle alınmamalı, \%8'i kesinlikle derse alınmalı, \%4'ü ise spor sahası dışında başka bir işle görevlendirilmelidir şeklinde görüş belirtmişlerdir (Tablo 23).

\section{Sonuç ve Öneriler}

Sonuç olarak, beden eğitimi ve spor dersini okutan öğretmenlere göre, Niğde ili merkeze bağl1 ilköğretim okullarında, beden eğitimi ve spor dersinin amaçlarına uygun olarak okutulabilmesi için gerekli spor tesis, araç ve gereçlerinin yetersiz olduğu tespit edilmiştir. Ayrıca okulların yeterince mahalli spor tesis, araç ve gereçlerinden yararlanamadıkları, okul yönetimlerinin ve velilerin ilgisizliği, beden eğitimi ve spor öğretmenlerinin kendi derslerine yeterince önemi göstermedikleri, öğrencilerin boş zamanlarında beklenen düzeyde spor ve oyun faaliyetlerine katılmadıkları ve uygun ders kıyafetiyle derse gelmedikleri, öğretmenlerin mahalli idarelerin spor tesis, araç ve gereçler konusunda okullara yardım yapmak zorunda olduklarını bilmemeleri, okul yöneticilerinin bireysel olarak spora ilgi duymadıkları ve yeterince spor yapmadıkları tespit edilmiştir.

$\mathrm{Bu}$ itibarla beden eğitimi ve spor derslerinin amaçlarına uygun olarak okutulabilmesi için okul yöneticileri ve beden eğitimi ve spor dersini okutan öğretmenlerin okul dışı spor imkânlarından yeterince yararlanabilmeleri konusunda bilgilendirilmeleri yararlı olabilir. Öğrenci velileri toplantılarında anılan dersin yararları konusunda daha bilimsel bilgiler verilerek, velilerin beden eğitimi ve sporun yararları konusunda aydınlatılmaları sağlanmalıdır. Özellikle spor tesisleri ve okulların yapımında, planlamanın eşgüdümlü olarak yapılması sağlanmalıdır. Bu şekilde öğrencilerin okul dışı spor tesis, araç ve gereçlerinden daha fazla yararlanmaları sağlanmış olabilir. Böylece spor tesis, araç ve gereçlerinin azami düzeyde kullanımı sağlanarak tesislerin ekonomik kullanımı da gerçekleştirilmiş olacaktır. Daha çok öğrencinin spor faaliyetlerine katılımını sağlamada, velilerin maddi ve manevi desteklerinin artırılması ve bunun için çeşitli yardım kampanyalarının düzenlenmesi yararlı olabilir. Okul yöneticilerinin, beden eğitimi dersini okutan öğretmenlerin yanında diğer 
öğretmenlerin de spor yapmaya yönlendirilmeleri, öğrencilerin daha çok spor yapmalarında etkili olabilir. Bunun için resmi kurumlarca gerekli mevzuat değişikliklerinin yapılmasına da ihtiyaç duyulabilir.

\section{Kaynakça}

Bookwalter, KW., \& Van Der Zwag, HJ. (1969). Foundations and principles of physical education. Philadelphia, London, W.B. Saunders Comp.

Çumralıgil, B. (1995). Seçilmiş bazı illerdeki ortaöğretim kurumlarında beden eğitimi öğretiminin yapısı ve sorunları. (Yayınlanmamış doktora tezi). G.Ü. Sağlık Bilimleri Enstitüsü. Ankara.

Demirel, Ö. (2004). Kuramdan uygulamaya eğitimde program geliştirme. Pegem Yayınc1lık, Ankara.

Erden, E., \& Fidan, N. (1986). Eğitim bilimine giriş. Repa Eğitim Yayınları, Ankara.

Gaikwad, P. (2004). Curriculum pedagogy and values: Revealing the invisible.

www.aias.edu/academics/sgs/info/V7n2/GAIIKWAD.pdf. (Erişim: 27.10. 2018)

Gül, A., Küçük, V. (2001). Kentsel açık-yeşil alanlar ve Isparta kenti örneğinde irdelenmesi. Süleyman Demirel Üniversitesi Orman Fakültesi Dergisi, 2, 27-48.

Güllü, M., Cengiz, ŞŞ., \& Öztaşyonar, Y. (2016). Ortaokul öğrencilerin beden eğitimi ve spor dersine ilişkin tutumlarının bazı değişkenlere göre incelenmesi (Şanlıurfa Örneği). Gaziantep Üniversitesi Spor Bilimleri Dergisi, 1(2) - 49-61

Karasar, N. (1998). Bilimsel araştırma yöntemi. (8.Basım). Nobel Yayın Dağıtım, Ankara.

Kasap, H., Erdemli, A., Pınar, S., Kesim, Ü., Dugan, Ö., Erdemli, S. \& Gültekin, O. (2005). Çocuğun oyun ve spor hakkı, UNESCO. Türkiye Milli Komisyonu, Beden Eğitimi ve Spor İhtisas Komitesi Çalıstayl, Ankara Üniversitesi.

Koç, Ş. (1988). Orta ögretimde beden eğitimi etkinliklerine genel bir bakış. Yeni yaklaşım ve uygulamalar (amaç, yöntem ve teknikler), orta öğretim kurumlarında beden eğitimi ve sorunları, Ankara, Türk Eğitim Derneği VI. Öğretim toplantısı (5 - 6 Mayıs 1988)

Osborne, Kenneth, W. (1984). Political education or political socialization:the role of hidden curriculum. Monograghs In Education, (Edited By Alexander Gregor And Keith Wilson), University Of Manitoba.

Özener, R. (1998). Beden eğitiminde tesis, araç ve gereçlerin yeri ve önemi, orta öğretim kurumlarında beden eğitimi ve sorunları. Şafak Matbaacılık, Ankara,

Öztürk, F., \& Koçyiğit, F. (1992). İlkokul ve ilköğretim okullarında beden eğitimi dersi uygulama sorunu. Milli Eğitim Bakanlığı Okul İçi Beden Eğitimi Spor ve İzcilik Daire Başkanlığı, Milli Eğitim Basımevi, Ankara.

Semih, H., \& Emür, D. (2007). On sekiz, kentsel yaşam kalitesi bileşenleri arasında açık ve yeşil alanların önemi - Kayseri/Kocasinan ilçesi park alanları analizi, Sosyal Bilimler Enstitüsü Dergisi, 22(1), 367-396.

Sorguç, B. (1990). Eğitim ve öğretim kurumlarında spor komisyonu raporu, spor şurası, 1990, T.C. Başbakanlık Gençlik ve Spor Genel Müdürlüğü, Ankara.

Sönmez, G. (1989). İlkokullarda beden eğitimi dersi uygulamaları ile ilgili sorunlar.(Yayınlanmamış Yüksek Lisans Tezi). Gazi Üniversitesi Sağlık Bilimleri Enstitüsü, Ankara.

TÜIK, www.tuik.gov.tr/PreIstatistikTablo.do?istab_id=1606. Erişim 12. 10. 2018

Yılmaz, S., \& Bulut, Z. (2002). Kentsel mekanlarda çocuk oyun alanları planlama ve tasarım ilkeleri, Atatürk Üniversitesi. Ziraat Fakültesi. Dergisi. 33(3), 345-351. 